\title{
Effect of thyme essential oil on productive performance of broiler chickens a-review
}

\author{
Fawaz M.A. ${ }^{1}$, Z.S.H. Ismail ${ }^{2}$, H.A. Hassan ${ }^{1}$, and A.A.A. Abdel-Wareth ${ }^{1}$ \\ ${ }^{I}$ Department of Animal and Poultry Production, Faculty of Agriculture, South Valley University, Qena 83523, \\ Egypt. \\ ${ }^{2}$ Department of Poultry Production, Faculty of Agriculture, Suhag University, Egypt.
}

\begin{abstract}
Phytogenic can be supplemented to diet as an alternative to ameliorate activities of digestive enzyme and therefore improving broilers performance. Thyme essential oil has the biological activity of substances with different chemical compositions and concentrations which can play important roles in antioxidative, antigenotoxic, and antimicrobial. In addition to improving immune response and kidney and liver function of broiler. The scientific goal of this study is to give an overview of the effect of thyme (Thymus vulgaris $L$ ) on performance, carcass characteristics, nutrient digestibility, and some blood biochemistry of broilers.
\end{abstract}

Keywords: Blood biochemistry; Carcass; Performance; Thyme

\section{Introduction:}

Thyme (Thymus vulgaris $L$ ), is an aromatic herb a species of the Lamiaceae family, a culinary spice is widely used in herbal medicine improved the immune system, and antioxidative, antigenotoxic and antimicrobial (Mimica-Dukic et al. 2004; De Martino et al.2009). volatile essential oils can control pathogenic bacteria, the stimulation of digestive enzyme activity, improving nitrogen absorption and control excreta odour and ammonia concentration (Hippenstiel et al., 2011; Sethiya, 2016; AbdelWareth, 2016). Essential oils have the biological activity of substances with different chemical composition and concentration (Simitzis, 2017). Studies have also shown that the major biological activity of substances from thyme oil are thymol and carvacrol, its percentage are

*Corresponding author: Ahmed Abdel-Wareth Email: a.wareth@agr.svu.edu.eg Received: February 5, 2021; Accepted: February 20, 2021; Published online: February 22, 2021. (C) Published by South Valley University.

This is an open access article licensed under (C)(1)(2)
(28.53\%) and (25.06\%) respectively (Abbasi et al. 2020). There is also some proof that thymol and carvacrol responsible for antioxidant activity (Deighton et al.,1993; Aljabeili et al., 2018). This substance as phenolic commonly used as antimicrobial material (El-Ghousein and AlBeitawi, 2009; Toghyani et al., 2010). Moreover those studies, 0.1 and $0.5 \%$ thyme had a significant decrease $(\mathrm{p}<0.05) \quad E$. coli concentration in the hens feces (Bölükbaşi and Erhan 2007). However, Lactic acid bacteria number in ileal was significantly increased when broilers fed diet added with $0.1 \%$ thyme extract (Rahimi et al., 2011; Sigolo et al., 2021).

As summarized by Mansoub, (2010) carvacrol in herbs or their essential oils led to an increasing the digestive enzymes which enhanced pancreatic secretions. that may be beneficial to improved digistibility. Productive performance, serum glucose and cholesterol concentration were improved in broiler fed diet 
supplemented with $200 \mathrm{mg}$ thyme oil $/ \mathrm{kg}$ (AlMashhadani, et al 2011). Likewise, Wade et al., (2018) who indicated that body weight gain and feed conversion ratio were significantly improved when broiler fed diet added with $100 \mathrm{mg} / \mathrm{kg}$ diet compared to control group. Supplementation of thyme essential oil at 150 and $200 \mathrm{mg} / \mathrm{kg}$ is a suitable strategy to improve immune system and reduce the negative effects of heat stress (Olfati and Mojtahedin, 2018). It was indicated that during the period from 1 to 28 days of age, high level of thyme at $1 \mathrm{~g} / \mathrm{kg}$ had been improved immune responses for broiler chickens under heat stress (Attia et al., 2017; Fallah and Mirzaet 2016). there was a clear improved in productive performance of broiler consumed $0.5,1,1.5$ and $2 \%$ thyme powder in addition to decreased Mortality rate (ElGhousein and Al-Beitawi, 2009). Supplementation of thyme essential oil at 150 and $200 \mathrm{mg} / \mathrm{kg}$ broilers diet had been reduced adverse effect of heat stress on performance and immune responses (Khafar et al., 2019). Additionally, Nazarizadeh et al. (2019) discovered that Supplementation of $3 \mathrm{~g} / \mathrm{kg}$ thyme essential oil to broiler diet can be a good alternative to improve the adverse impact of aflatoxin B1 contaminated in diet at $0.5 \mathrm{mg} / \mathrm{kg}$. The scientific goal of this study is to give an overview on effect of thyme (Thymus vulgaris L) on performance, carcass characteristics, nutrient digestibility, and some blood biochemistry of broilers.

\section{Performance of broiler}

\subsection{Feed intake:}

Under heat stress condition, supplementation of thyme essential oil at 150 and $200 \mathrm{mg} / \mathrm{kg}$ had been significantly increased feed intake of broilers compared to control group (Khafar et al., 2019). Additionally, Saleh et al. (2014) added different level of thyme oil at 100,200 and $300 \mathrm{mg} / \mathrm{kg}$ and observed a significant $(\mathrm{P}<0.05)$ increase in feed intake when broilers consumed 100 and $200 \mathrm{mg} / \mathrm{kg}$ compared with control group. Thus, Addition of thyme powder at $5 \mathrm{~g} / \mathrm{kg}$ significantly increased feed intake in broiler when compared to control group (Fallah and Mirzaet 2016). Likewise, Bölükbaşi et al., (2006) stated that supplemented thyme oil at 100 and $200 \mathrm{mg} / \mathrm{kg}$ and indicated a significant increase in feed intake of broiler compared to control group. Also, Al-Kassie (2009) Found a significant increased $(\mathrm{p}<0.05)$ in Feed intake of broiler consumed 200 ppm from thyme essential oil for 6 weeks compared to control group. In addition, Feed intake was significantly higher in broilers fed diet added with thyme oil at 0.5 and $1 \mathrm{~g} / \mathrm{kg}$ compared to control group (Pournazari et al. 2017).

On other hand, dietary including thyme essential oil at $100 \mathrm{mg} / \mathrm{kg}$ did not effect on feed intake of broilers (Moustafa et al., 2020). Thus, Hashemipour et al. (2013) reported that 60, 100 and $200 \mathrm{mg} / \mathrm{kg}$ thymol and carvacrol in broiler diet linearly $(\mathrm{P}<0.001$; quad $\mathrm{p}<0.003)$ increased FCR in broiler compared to control group. Likewise, Additionally, Demir et al. (2008) found that feed intake did not change in broiler fed diet supplemented with $1 \mathrm{~g}$ thyme powder $1 \mathrm{~g}$ $/ \mathrm{kg}$ compared with control group. Likewise, Wade et al., (2018) who noted that supplementation of different level of thyme oil at 100,200 and $300 \mathrm{mg} / \mathrm{kg}$ to broiler diet did not affect feed intake. In addition, high level of thyme oil 1.5 and $2 \mathrm{~g} / \mathrm{kg}$ cannot influence feed intake (Attia et al., 2017). Thus, for 42 day feeding, non-significant effect was observed in daily feed intake of broiler fed thyme powder at 5 and $10 \mathrm{~g} / \mathrm{kg}$ (Toghyani et al., 2010). Feed intake did not affect in broiler consumed 0.3 and $0.6 \%$ of thyme extract (Amouzmehr et al., 2012). Dietary including thyme powder at $1 \mathrm{~g} / \mathrm{kg}$ did not changed feed intake value in broiler 
(Sarica et al., 2005). Feed intake was nonsignificant increase in broiler fed diet supplemented with thyme extract levels $0.2,0.4$ and $0.6 \%$ compared to control group (Pourmahmoud et al., 2013). Likewise, Tekeli et al. (2006) who added thyme oil to broiler diet at $120 \mathrm{mg} / \mathrm{kg}$ and noted that feed intake was nondifferent effect. Non- significant different was noted in feed intake when broilers consumed 0.05 and $0.1 \%$ thyme essential oil for 28 day (Placha et al., 2019). Thus, Fallah and Mirzaet., (2016) who noted that broilers feeding thyme powder at $5 \mathrm{~g} / \mathrm{kg}$ diet had non-significant different in final body weight compared to control group. In addition, Gradual addition of thyme oil from 0.05 up to $0.35 \mathrm{mg} / \mathrm{kg}$ broilers diet did not effect on feed intake (Zhu et al., 2014).

However, feed intake was significantly lower in group fed diet supplemented with thyme powder at $1 \mathrm{~g} / \mathrm{kg}$ compared to control group (Ragaa et al., 2016). there was a clear significant decrease $(\mathrm{p}<0.05)$ in feed intake when broiler fed from $0.5 \%$ up to $2 \%$ thyme powder compared to control group (El-Ghousein and Al-Beitawi, 2009). Likewise, Cross et al. (2003) observed a significant decrease of feed intake from day 8 till 14 When broiler received relatively high amounts $(5 \mathrm{~g} / \mathrm{kg})$ of thyme oil were supplemented. (Bölükbaşi \& Erhan 2007) demonstrated that supplementation of $1 \%$ thyme to hens diet significantly $(\mathrm{p}<0.05)$ decrease in feed intake. In addition, Sariözkan et al. (2020) reported a significant $(\mathrm{p}<0.05)$ decrease in feed intake of broilers consumed $300 \mathrm{mg} / \mathrm{kg}$ thyme essential oil compared to control group. Likewise, a significant $(\mathrm{p}<0.05)$ decrease in feed intake was observed in broilers fed diet added with 100,150 and $200 \mathrm{mg} / \mathrm{kg}$ thyme essential oil (Khafar et al. 2019). There was a significant $(\mathrm{p}<0.05)$ decrease in feed intake when broilers fed thyme oil at $0.4 \mathrm{ml}$ per $\mathrm{kg}$ diet from 7-35 day of age compared to control group (Shamma et al. 2019).

\subsection{Body weight gain:}

Many studies had been reported that thyme (Thymus vulgaris $L$ ) can inhanced growth rate of broilers. This was evident in the research conducted by, Wade et al. (2018) who Observed a significant improved in body weight gain when broiler fed diet supplemented with thyme oil at $100 \mathrm{mg} / \mathrm{kg}$ compared to control group. In addition, Khafar et al., (2019) who indicated that body weight gain was significantly $(\mathrm{p}<0.05)$ higher in broilers fed diet added with thyme essential oil at 150 and 200 $\mathrm{mg} / \mathrm{kg}$ under heat stress condition compared to control group. Additionally, Moustafa et al. (2020) who indicated that supplementation of thyme essential oil at $100 \mathrm{mg} / \mathrm{kg}$ had been significantly $(\mathrm{p}<0.05)$ increased body weight gain of broilers compared to control group. Likewise, Zhu et al. (2014) supplemented gradual level of thyme oil from 0.05 up to 0.35 $\mathrm{mg} / \mathrm{kg}$ diet and observed a significant increase in body weight gain of broilers consumption up to $0.30 \mathrm{mg} / \mathrm{kg}$ thyme oil compared to control group. Also, Toghyani et al., (2010) who indicated that there was a clear increased $(p<0.05)$ in body weight gain of broiler fed diet added with $5 \mathrm{~g}$ thyme powder $/ \mathrm{kg}$ compared to control group. El-Ghousein and Al-Beitawi, (2009) noted that body weight gain was higher $(p<0.05)$ in broilers fed $0.5,1,1.5$ and $2 \%$ crushed thyme compared to control group. Thus, Cross et al. (2007) found a significant increase in body weight gain when broiler received diet supplementing with thyme essential oil at $1 \mathrm{~g} / \mathrm{kg}$ compared to control group. Treatments 100 and $200 \mathrm{ppm}$ of thyme oil had a significant $(\mathrm{p}<0.05)$ improvement in broiler body weight gain compared to control group (Al-Kassie 2009). In addition, Pournazari et al. (2017) who reported that body weight gain was significantly increased $(\mathrm{p}<0.05)$ in broiler fed 0.5 and $1 \mathrm{~g} / \mathrm{kg}$ 
thyme oil from 1 to 42 day of age compared to control group. Hashemipour et al. (2013) compared the effects of dietary thymol and carvacrol supplementation at 60, 100 and 200 $\mathrm{mg} / \mathrm{kg}$ on broiler performance, they found a linear increased in $(\mathrm{p}<0.001)$ average body weight gain with increased level of supplementation. Thus, Ragaa et al. (2016) noted that $1 \mathrm{~g} / \mathrm{kg}$ thyme powder supplementation to broilers diet had a significant $(\mathrm{p}<0.01)$ increased in body weight gain compared to without supplemented broilers.

On other side, dietary added with thyme essential oil at 0.05 and $0.1 \%$ had been nonsignificant effect on body weight gain of broiler chickens (Placha et al., 2019). Likewise, Saleh et al. (2014) who noted that body weight gain was not affected in broiler fed diet supplemented with thyme oil level 100,200 and $300 \mathrm{mg} / \mathrm{kg}$. in addition, non-significant different observed in broiler fed $0.1 \%$ thyme powder (Demir et al. 2008). Likewise, Attia et al., (2017) who found that body weight gain did not impact in broiler fed diet supplemented with thyme oil at 1, 1.5, $2 \mathrm{~g} / \mathrm{kg}$. In addition, Amouzmehr et al., (2012) reported that non- significant improved was observed in body weight gain when broiler consumed 0.3 and 0,6 thyme extract. For 42 day feeding, body weight gain was non- significant influence in broiler fed diet supplemented with $1 \mathrm{~g} / \mathrm{kg}$ thyme powder compared to control group (Sarica et al., 2005). body weight gain was nonsignificant affect in broiler fed diet supplemented with thyme extract levels $0.2,0.4$ and $0.6 \%$ for 42 day compared to control group (Pourmahmoud et al., 2013). There was nonsignificant different in body weight gain between treatment groups when broiler fed dietary added with $120 \mathrm{mg} / \mathrm{kg}$ thyme oil (Tekeli et al., 2006). In addition, Sadeghi et al. (2012) found that average daily body weight gain had non-significant effect in broilers consumed water supplemented with thyme herb at $5 \mathrm{~g} /$ litter. Broilers received thyme oil at $0.4 \mathrm{ml}$ per $\mathrm{kg}$ diet from 7-35 day of age had non-significant differences compared to without supplemented broilers (Shamma et al. 2019).

Conversely, body weight gain was lower $(\mathrm{p}<0.05)$ in broilers fed $300 \mathrm{mg} / \mathrm{kg}$ thyme essential oil compared to control group (Sariözkan et al. 2020). Thus, Khafar et al. (2019) observed that supplementation of thyme oil at 100, 150 and $200 \mathrm{mg} / \mathrm{kg}$ had a significantly decreased $(\mathrm{p}<0.05)$ body weight gain compared to control group.

\subsection{Feed conversion ratio}

Several researchers had been showed that dietary including different level of thyme oil or their active components did improve feed conversion ratio. For example, Moustafa et al. (2020) reported that supplementation of thyme oil at $100 \mathrm{mg} / \mathrm{kg}$ had been improved feed conversion ratio of broilers compared to control group. Additionally, Ragaa et al., (2016) observed a significant improved in FCR when broiler consumed diet supplemented with thyme powder at $1 \mathrm{~g} / \mathrm{kg}$ compared to control group. Likewise, Zhu et al. (2014) reported that feed conversion ratio was significantly decreased in broilers fed gradual level of thyme oil from 0.1 up to $0.35 \mathrm{mg} / \mathrm{kg}$ compared to control group. Also, El-Ghousein and Al-Beitawi,. (2009) who found that supplementation of crushed thyme level $0.5,1,1.5$ and $2 \%$ significantly $(\mathrm{p}<0.05)$ decreased feed conversion ratio compared to control group. (Al-Kassie 2009) supplemented of thyme essential oil at 100 and $200 \mathrm{ppm}$ to broiler diet and observed a significant $(\mathrm{p}<0.05)$ decrease in feed conversion ratio compared to control group. Thus, Pournazari et al. (2017) who observed a significant improved $(\mathrm{p}<0.05)$ in FCR of broiler fed $1 \mathrm{~g} / \mathrm{kg}$ thyme oil from 1 to 42 day of age compared to control group. In addition, $1 \mathrm{~g} / \mathrm{kg}$ thyme powder addition to broilers dietary had a significant $(\mathrm{p}<0.01)$ 
reduced feed conversion ratio compared to control group (Ragaa et al. 2016). from 7-35 day of age, An improvement ( $\mathrm{p}<0.05)$ was observed in broilers consumed thyme oil at $0.4 \mathrm{ml}$ per $\mathrm{kg}$ diet from 7-35 day of age compared to control group (Shamma et al. 2019). Additionally, under heat stress feed conversion ratio was improved when broilers received thyme essential oil at 150 and $200 \mathrm{mg} / \mathrm{kg}$ compared to control group (Khafar et al., 2019). Thus,

On the other side, Placha et al., (2019) indicated that dietary supplemented with thyme essential oil at 0.05 and $0.1 \%$ had been nonsignificant different when compared to control group. Likewise, Saleh et al. (2014) supplementation of thyme essential oil at 100,200 and $300 \mathrm{mg} / \mathrm{kg}$ broiler diet did not effect on feed conversion ratio. Thus, same level of thyme oil cannot effect on feed conversion ratio (Wade et al., 2018). In addition, no differences in FCR value observed in broiler fed diet added with thyme oil at $1,1.5$ and $2 \mathrm{~g} / \mathrm{kg}$ (Attia et al., 2017). In addition, Fallah and Mirzaet (2016) who demonstrated that supplementation of thyme powder at $5 \mathrm{~g} / \mathrm{kg}$ individual or in mix with turmeric powder did not affect in FCR of broiler. There was nonsignificant differences in feed conversion ratio when broiler consumed 0.3 and 0,6 thyme extract (Amouzmehr et al., 2012). Thus, Sarica et al., (2005) stated that $1 \mathrm{~g} / \mathrm{kg}$ thyme powder inclusion in feed did not significantly affect feed conversion ratio. There was non-significant differences in FCR of broiler fed diet supplemented with thyme extract levels $0.2,0.4$ and $0.6 \%$ (Pourmahmoud et al., 2013). Tekeli et al., (2006) reported that feed conversion ratio was non- significant effect in broiler fed thyme oil at $120 \mathrm{mg} / \mathrm{kg}$ diet. Hashemipour et al. (2013) pointed out that 60,100 and $200 \mathrm{mg} / \mathrm{kg}$ thymol and carvacrol in broiler diet did not effect on average daily feed intake. Average daily feed intake was not affected in broilers consumed thyme powder $5 \mathrm{~g}$ / litter of water drink from 1-21 day of age (Sadeghi et al. 2012).

However, Khafar et al. (2019) who found a significant $(\mathrm{p}<0.05)$ increased feed conversion ratio when broilers fed diet added with 100 and $150 \mathrm{mg} / \mathrm{kg}$ thyme oil. Likewise, However, Bölükbaşi et al., (2006) noted that FCR was significantly increased in broiler fed thyme oil at 100 and $200 \mathrm{mg} / \mathrm{kg}$ compared to control group.

\section{Effect of thyme on carcass characteristics:}

Hot carcass and Liver weight were significantly decreased in broiler fed diet added with thyme oil at $100 \mathrm{mg} / \mathrm{kg}$ compared to control group (Bölükbaşi et al., 2006). Liver, spleen, heart, gizzard and Pancreas weight were non-significant affected in broiler consumed thyme powder at $1 \mathrm{~g} / \mathrm{kg}$ compared to control group (Sarica et al., 2005). Same result was indicated, Pourmahmoud et al., (2013) who found that internal parts (Liver, spleen, heart, gizzard Pancreas and abdominal fat) were nonsignificant affected when broiler fed thyme extract at $0.2,0.4$ and $0.6 \%$. Thus, Tekeli et al., (2006) supplemented thyme oil at $120 \mathrm{mg} / \mathrm{kg}$ to broiler diet and noted that hot carcass and abdominal fat were not affected. Nonsignificant differences was observed in Pancreas, liver, bile, spleen and gizzard percentage in broiler consumed dietary added with thyme oil at 0.5 and $1 \mathrm{~g} / \mathrm{kg}$ compared to control group (Pournazari et al. 2017). It has been found that hot carcass; liver and heart were non-significant affected in broiler fed $300 \mathrm{mg} / \mathrm{kg}$ thyme oil (Sariözkan et al. 2020). Relative weight of internal parts of broilers (spleen, Pancreas, Cecum, liver and heart) weight were non-significant affect when broilers consumed thyme powder at $5 \mathrm{~g}$ / litter drink water however, gizzard weight had a significant increase compared to control group (Sadeghi et al. 2012). 


\section{Effect of thyme on blood biochemistry:}

\subsection{Cholesterol}

Total cholesterol was significantly $(\mathrm{p}<0.01)$ decreased in broilers fed thyme oil at 150 and $200 \mathrm{mg} / \mathrm{kg}$ compared to control group (Khafar et al., 2019). Additionally, Serum concentration of total cholesterol was significantly $(\mathrm{p}<0.01)$ lower in quails fed diet added with 300 and $450 \mathrm{mg} / \mathrm{kg}$ than control group (Gumus et al. 2017). Thus, Hassan. (2019) indicated that supplementation of thyme oil at $100 \mathrm{mg} / \mathrm{kg}$ had been significantly reduced Serum total cholesterol compared to control group. Likewise, (Shamma et al., 2019) found that addition of thyme oil at $0.4 \mathrm{ml} / \mathrm{kg}$ diet significantly $(\mathrm{p}<0.05)$ decreased Serum total cholesterol of broilers compared to control group. El-Ghousein and Al-Beitawi, (2009) observed a significant decrease $(p<0.05)$ in serum total cholesterol when broiler consumed from $0.5 \%$ up to $2 \%$ thyme powder compared to control group. In addition, Moomivand et al. (2015) noted that serum total cholesterol was significantly lower in broilers received drinking water supplemented with $0.1,0.15$ and $0.2 \mathrm{ml} /$ liter compared to control group. Similar results were indicated in broilers according to Abdulkarimi et al. (2011) who indicated that addition of Thymus vulgaris (thyme) extract at $0,2,0.4$ and $0.6 \%$ to drinking water of broilers resulted in a significant $(\mathrm{p}<0.01)$ decreased in serum total cholesterol and low-density lipoprotein (LDL) compared to control group. Thus, Rahimi et al. (2011) Indicated that addition of thyme extract at $0.1 \%$ to broilers diet had been significantly decreased $(p<0.05)$ serum total cholesterol compared to control group. Also, Moustafa et al. (2020) reported that addition of thyme oil at $100 \mathrm{mg} / \mathrm{kg}$ significantly reduced serum total cholesterol and LDL of broilers however HDL was increased compared to control group.
On the other hand, there was nonsignificant change in serum concentration of total cholesterol when broilers received thyme extract at $0.3 \%$ and $0.6 \%$ (Amouzmehr et al., 2012). Additionally, Sarica et al. (2005) indicated that supplementation of thyme powder at $1 \mathrm{~g} / \mathrm{kg}$ diet did not effect on serum total cholesterol of broilers. Also, serum total cholesterol and LDL did not affect when broilers fed dietary added with gradual level of thyme oil from 0.05 up to $0.35 \mathrm{mg} / \mathrm{kg}$, however HDL was lower in broilers received 0.1 and $0.15 \mathrm{mg}$ TO $/ \mathrm{kg}$ diet compared to control group (Zhu et al., 2014).

\subsection{Alanine transaminase (ALT)}

Moustafa et al. (2020) found that supplementation of thyme oil at $100 \mathrm{mg} / \mathrm{kg}$ diet had been significantly $(\mathrm{p}<0.05)$ decreased serum content of alanine transaminase compared with control group. Also, Serum concentration of alanine transaminase was significantly $(p<0.05)$ higher in broilers fed dietary supplemented with $0.05,0,1,0.15,0.2$ and 0.35 $\mathrm{mg} / \mathrm{kg}$ than control group (Zhu et al., 2014)

Dietary including $1 \mathrm{~g}$ thyme powder $/ \mathrm{kg}$ did not affect serum Alanine transaminase enzyme in broiler chicken (Ragaa et al., 2016). Likewise, the study by Saleh et al., (2014) who found that supplementation of thyme oil at 100, 200 and $300 \mathrm{mg} / \mathrm{kg}$ had non- significant differences in serum concentration of AST of broilers. In addition, Tayeb et al. (2019) studied the effect of thyme powder on broilers and observed that $10 \mathrm{~g} / \mathrm{kg}$ thyme powder did not affect serum concentration of Alanine transaminase.

\subsection{Aspartate transaminase (AST)}

Attia et al., (2017) demonstrated that (AST) enzyme was significantly decreased in broiler consumed $1,1.5$ ang $2 \mathrm{~g} / 1 \mathrm{~kg}$ when compared to control group. Likewise, Moustafa 
et al. (2020) who proposed that dietary inclusion of $100 \mathrm{mg} / \mathrm{kg}$ thyme essential oil had been significantly reduced serum concentration of Aspartate transaminase of broilers compared to control group.

However, Ragaa et al., (2016) found that serum concentration of AST enzyme did not affected in broiler fed diet supplemented with thyme powder at $1 \mathrm{~g} / \mathrm{kg}$ compared to control group. Likewise, Saleh et al., (2014) who noted that addition of thyme oil at 100, 200 and 300 $\mathrm{mg} / \mathrm{kg}$ to broiler diet had non- significant effect on serum concentration of AST. Thus, there was not influence in serum content of AST in broilers fed diet added with thyme powder at $10 \mathrm{~g} / \mathrm{kg}$ (Tayeb et al., 2019). Also, serum content of aspartate transaminase was not affected in broilers fed gradual level of thyme oil from 0.1 up to $0.35 \mathrm{mg} / \mathrm{kg}$ diet (Zhu et al., 2014).

\subsection{Creatinine}

Treatments 150,300 and $450 \mathrm{mg} / \mathrm{kg}$ of thyme oil had a linear $(\mathrm{p}<0.01)$ decrease in quails serum content of creatinine compared to control group (Gumus et al. 2017). However, Broiler that received $1 \mathrm{~g} / \mathrm{kg}$ of thyme powder did not showed any different in serum concentration of creatinine (Ragaa et al., 2016). In addition, Serum concentration of creatinine was significantly $(\mathrm{p}<0.05)$ increased in broiler fed thyme powder at $10 \mathrm{~g} / \mathrm{kg}$ compared to nontreated broilers (Tayeb et al., 2019).

There were non-significantly improve observed in serum concentration of creatinine in broilers received diet added with thyme oil at $100 \mathrm{mg} / \mathrm{kg}$ (Moustafa et al., 2020)

\subsection{Urea concentration}

Serum content of uric acid was nonsignificant affect $(p>0.05)$ in broiler fed diet added with $1 \mathrm{~g} / \mathrm{kg}$ diet (Ragaa et al., 2016). Likewise, Fallah and Mirzaet., (2016) who noted that broilers receiving thyme powder at $5 \mathrm{~g} / \mathrm{kg}$ diet had non-significant effect in serum concentration of uric aside compared to control group. For 42-day broiler feeding, Pournazari et al. (2017) noted that dietary including 0.5 and $1 \mathrm{~g} / \mathrm{kg}$ thyme oil did not affect serum concentration of uric acid. Thus, non- significant effects were observed in serum concentration of uric acid when broilers consumed water drink contained $0.1,0.15$ and $0.2 \%$ thyme essence (Moomivand et al., 2015). Also, Zhu et al. (2014) indicated that blood uric acid had been non-significant different in broilers fed gradual level of thyme oil from 0.1 up to $0.35 \mathrm{mg} / \mathrm{kg}$ diet. However, a significant reduction $(\mathrm{p}<0.001)$ was observed in serum concentration of urea when layers fed thyme powder at 6 and $9 \mathrm{~g} / \mathrm{kg}$ diet compared to control group (Abd El-Hack and Alagawany 2015).

\subsection{Hormones}

There were non- significant differences in Thyroid hormone (Triiodothyronine and thyroxine) concentration when broilers fed $10 \mathrm{~g} / \mathrm{kg}$ thyme powder (Tayeb et al., 2019). additionally, serum contain of Triiodothyronine (T3) was significantly higher in broilers fed diet added with thyme oil at $100 \mathrm{mg} / \mathrm{kg}$ than control group, however, thyroxine $\mathrm{T} 4$ was not affected (Hassan, 2019).

Under heat stress condition, supplementation of thyme oil at 150 and 200 $\mathrm{mg} / \mathrm{kg}$ diet had been significantly decreased serum concentration of corticosterone compared to control group (Khafar et al., 2019).

\section{Nutrient digestibility}

From 7 to 28 day of age dietary including $120 \mathrm{mg} / \mathrm{kg}$ thyme oil result in nonsignificant improved in nitrogen metabolisability, dry matter and organic matter digestibility (Cross et al., 2007). In addition, Hashemipour et al. (2013) reported that 
supplementation of 60,100 and $200 \mathrm{mg} / \mathrm{kg}$ thymol and carvacrol to broilers diet linearly increased $(p<0,05)$ activities of digestive enzyme (trypsin, protease and lipase) from 1 to 24 day of age, however, there were not affect at 42 day of age.

\section{CONCLUSION}

It can be concluded that thyme essential oil has the potential to improving performance and health status of broilers. Additional, improving liver and kidney functions, there is still further research under standardized conditions needed to evaluate optimal dietary inclusion level in order to optimize nutrient retentions and maintain healthy birds.

\section{References}

Abbasi, M.A., Ghazanfari, S., Sharifi, S.D., Ahmadi Gavlighi. (2020). 'Influence of dietary plant fats and antioxidant supplementations on performance, apparent metabolizable energy and protein digestibility, lipid oxidation and fatty acid composition of meat in broiler chicken', Veterinary Medicine and Science, 6(1), pp. 54-68.

Abd El-Hack, M.E., Alagawany, M. (2015). 'Performance, egg quality, blood profile, immune function, and antioxidant enzyme activities in laying hens fed diets with thyme powder', Journal of Animal and Feed Sciences, 24, pp. 127-33.

Abdel-Wareth, A.A.A. (2016). 'Effect of dietary supplementation of thymol, synbiotic and their combination on performance, egg quality and serum metabolic profile of $\mathrm{Hy}$ Line Brown hens', British poultry science, 57, pp. 114-122.

Abdulkarimi, R., Daneshyar, M., Aghazadeh, A. (2011). 'Thyme (Thymus vulgaris) extract consumption darkens liver, lowers blood cholesterol, proportional liver and abdominal fat weights in broiler chickens', Italian Journal of Animal Science, 10:e20.

Al-Kassie, G.A. (2009). 'Influence of two plant extracts derived from thyme and cinnamon on broiler performance', Pakistan Veterinary Journal, 29, pp. 169-73.

Al-Mashhadani, E.H., Farah, K., Al-Jaff, Y., Farhan, Y.M. (2011). 'Effect of anise, thyme essential oils and their mixture (EOM) on broiler performance and some physiological traits', Egyptian Poult Sci, 31(2), 481-489.

Aljabeili, H.S., Barakat, H., Abdel-Rahman, H.A. (2018). 'Chemical composition, antibacterial and antioxidant activities of Thyme essential oil (Thymus vulgaris)', Food and Nutrition Sciences, 9:433.

Amouzmehr, A., Dastar, B., Nejad, J.G., Sung, K.-I., Lohakare, J., Forghani, F. (2012). 'Effects of garlic and thyme extracts on growth performance and carcass characteristics of broiler chicks', Journal of Animal Science and Technology, 54, pp. 185-190.

Attia, Y.A., Bakhashwain, A.A., Bertu, N.K. (2017). 'Thyme oil (Thyme vulgaris L.) as a natural growth promoter for broiler chickens reared under hot climate', Italian Journal of Animal Science, 16(2), pp. 275282.

Bölükbaşi, Ş.C., Erhan, M.K., Özkan, A. (2006). 'Effect of dietary thyme oil and vitamin E on growth, lipid oxidation, meat fatty acid composition', South African Journal of Animal Science, 36(3), pp. 189-196.

Bölükbaşi, Ş.C., Erhan M.K. (2007). 'Effect of Dietary Thyme (Thymus vulgaris) on Laying Hens Performance and Escherichia coli (E. coli) Concentration in Feces', International Journal of Natural \& Engineering Sciences 1.

Cross, D., McDevitt, R., Hillman, K., Acamovic, T. (2007). 'The effect of herbs and their associated essential oils on performance, 
dietary digestibility and gut microflora in chickens from 7 to 28 days of age', British poultry science, 48, pp. 496-506.

Cross, D., Svoboda, K., McDevitt, R., Acamovic, T. (2003). 'The performance of chickens fed diets with and without thyme oil and enzymes', British Poultry Science, 44 (S1), pp. 18-19.

Deighton, N., Glidewell, S.M., Deans, S.G., Goodman, B.A. (1993). 'Identification by EPR spectroscopy of carvacrol and thymol as the major sources of free radicals in the oxidation of plant essential oils', Journal of the Science of Food and Agriculture, 63, pp. 221-225.

Demir, E., Kilinc, K., Yildirim, Y., Dincer, F., Eseceli, H. (2008). 'Comparative effects of mint, sage, thyme and flavomycin in wheat-based broiler diets', Archiva Zootechnica, 11(3), pp. 54-63.

De Martino, L., De Feo, V., Fratianni, F., Nazzaro, F. (2009). 'Chemistry, antioxidant, antibacterial and antifungal activities of volatile oils and their components', Nat Prod Commun, 4, pp. 1741-50.

El-Ghousein, S.S., Al-Beitawi, N.A. (2009). 'The effect of feeding of crushed thyme (Thymus valgaris L) on growth, blood constituents, gastrointestinal tract and carcass characteristics of broiler chickens', The Journal of Poultry Science, 46, pp.100-104.

Fallah, R., Mirzaei, E. (2016). 'Effect of Dietary inclusion of turmeric and thyme powders on performance, blood parameters and immune system of broiler chickens', $J$ Livestock Sci, 7, pp.180-186.

Hashemipour, H., Kermanshahi, H., Golian, A., Veldkamp, T. (2013). 'Effect of thymol and carvacrol feed supplementation on performance, antioxidant enzyme activities, fatty acid composition, digestive enzyme activities, and immune response in broiler chickens', Poultry science, 92, pp. 2059-69.

Hippenstiel, F., Abdel-Wareth, A.A.A., Kehraus, S., Südekum, K. (2011). 'Effects of selected herbs and essential oils, and their active components on feed intake and performance of broilers-a review', Arch. Geflügelk, 75, pp. 226-234.

Mansoub, N.H. (2010). 'Effect of probiotic bacteria utilization on serum cholesterol and triglycrides contents and performance of broiler chickens', Globaal Veterinaria, 5, pp. 184-186.

Mimica-Dukic, N., Bozin, B., Sokovic, M., Simin, N. (2004). 'Antimicrobial and antioxidant activities of Melissa officinalis L. (Lamiaceae) essential oil', J Agric Food Chem, 52, pp. 2485- 9.

Moomivand, H., Seif, Y., Taleghani, M., Oshtolag, A.M., Darzan, M. (2015). 'The effect of drinking thyme essence on proteins, enzymatic activity, serum biochemical parameters and hematological characteristics in broiler chicks', Int $J$ Biosci, 6, pp. 264-273.

Moustafa, N., Aziza, A., Orma, O., Ibrahim, T. (2020). 'Effect of supplementation of broiler diets with essential oils on growth performance, antioxidant status, and general health', Mansoura Veterinary Medical Journal, 21, pp. 14-20.

Nazarizadeh, H., Mohammad Hosseini, S., Pourreza, J. (2019). 'Effect of plant extracts derived from thyme and chamomile on the growth performance, gut morphology and immune system of broilers fed aflatoxin B1 and ochratoxin A contaminated diets', Italian Journal of Animal Science, 18, pp.1073-1081.

Olfati, A., Mojtahedin, A. (2018). 'Dietary inclusion of thyme essential oil alleviative effects of heat stress on growth performance and immune system of broiler chicks', J. Biotechnol., 1, pp. 60-71. 
Placha, I., Ocelova, V., Chizzola, R., Battelli, G., Gai, F., Bacova, K., Faix, S., (2019). 'Effect of thymol on the broiler chicken antioxidative defence system after sustained dietary thyme oil application', British poultry science, 60, pp. 589-596.

Pourmahmoud, B., Aghazadeh, A.M., Sis, N.M. (2013). 'The effect of thyme extract on growth performance, digestive organ weights and serum lipoproteins of broilers fed wheat-based diets', Italian Journal of Animal Science, 12:e53.

Pournazari, M., AA-Qotbi, A., Seidavi, A., Corazzin, M. (2017). 'Prebiotics, probiotics and thyme (Thymus vulgaris) for broilers: Performance, carcass traits and blood variables', Revista Colombiana de Ciencias Pecuarias, 30, pp. 3-10.

Khafar, K., Mojtahedin, A., Rastegar, N., Kalvani Neytali, M., Olfati, A. (2019). 'Dietary Inclusion of Thyme Essential Oil Alleviative Effects of Heat Stress on Growth Performance and Immune System of Broiler Chicks' Iranian Journal of Applied Animal Science, 9, pp. 509-17.

Ragaa, N.M., Korany, R.M., Mohamed, F. (2016). 'Effect of thyme and/or formic acid dietary supplementation on broiler performance and immunity', Agriculture and Agricultural Science Procedia, 10, pp. 270-279.

Rahimi, S., Teymouri, Z.Z., Karimi, T.M., Omidbaigi, R., Rokni, H. (2011). 'Effect of the three herbal extracts on growth performance, immune system, blood factors and intestinal selected bacterial population in broiler chickens', Journal of Agricultural Science and Technology, 13(4), 527-539

Sarica, S., Ciftci, A., Demir, E., Kilinc, K., Yildirim, Y. (2005). 'Use of an antibiotic growth promoter and two herbal natural feed additives with and without exogenous enzymes in wheat based broiler diets',
South African Journal of Animal Science, 35, 61-72.

Sadeghi, G., Karimi, A., Padidar Jahromi, S., Azizi, T., Daneshmand, A. (2012). 'Effects of cinnamon, thyme and turmeric infusions on the performance and immune response in of 1-to 21-day-old male broilers', Brazilian Journal of Poultry Science, 14, pp. 15-20.

Saleh, N., Allam, T., El-Latif, A., Ghazy, E. (2014). 'The effects of dietary supplementation of different levels of thyme (Thymus vulgaris) and ginger (Zingiber officinale) essential oils on performance, hematological, biochemical and immunological parameters of broiler chickens', Global Vet, 12, pp. 736-744.

Sariözkan, S., Güçlü, B.K., Konca, Y., Aktuğ, E., Kaliber, M., Beyzi, S.B., Şentürk, M. (2020). 'The effects of thyme essential oil and vitamin combinations on performance, carcass quality and oxidation parameters in broilers exposed to heat stress', Ankara Üniversitesi Veteriner Fakültesi Dergisi, 67, 357-64.

Sethiya, N K. (2016). 'Review on natural growth promoters available for improving gut health of poultry: an alternative to antibiotic growth promoters', Asian $J$ Poult Sci, 10, pp.1-29.

Shamma, T., El-Shafei, A., A El-Yazby, W. (2019). 'Productive Performance and some Blood Parameters of Broiler Chickens Fed Diets Supplemented with Thyme and Lavender Oils', Journal of Animal and Poultry Production, 10, pp. 359-63.

Sigolo, S., Milis, C., Dousti, M., Jahandideh, E., Jalali, A., Mirzaei, N., Rasouli, B., Seidavi, A., Gallo, A., Ferronato, G. (2021). 'Effects of different plant extracts at various dietary levels on growth performance, carcass traits, blood serum parameters, immune response and ileal microflora of Ross broiler chickens', 
Italian Journal of Animal Science, 20, 359-371.

Simitzis, P. E. (2017).'Enrichment of animal diets with essential oils-agreat perspective on improving animal performanceand quality characteristics of the derived products', Medicines, 4, pp. 35-52.

Tayeb, I., Artoshi, N., Sögüt, B. (2019). 'Performance of broiler chicken fed different levels thyme, adiantum, rosemary and their combination', The Iraqi Journal of Agricultural Science, 50, pp. 15221532.

Tekeli, A., Celik, L., Kutlu, H., Gorgulu, M. (2006). 'Effect of dietary supplemental plant extracts on performance, carcass characteristics, digestive system development, intestinal microflora and some blood parameters of broiler chicks', In Proceedings of 12th European Poultry Conference, pp. 10-14.

Toghyani, M., Tohidi, M., Gheisari, A.A., Tabeidian, S.A. (2010). 'Performance, immunity, serum biochemical and hematological parameters in broiler chicks fed dietary thyme as alternative for an antibiotic growth promoter', African Journal of Biotechnology, 9, pp. 68196825.

vGumus, R., Ercan, N., Imik, H. (2017). 'The effect of thyme essential oil (Thymus vulgaris) added to quail diets on performance, some blood parameters, and the antioxidative metabolism of the serum and liver tissues', Brazilian Journal of Poultry Science, 19, pp. 297-304.

Wade, M., Manwar, S., Kuralkar, S., Waghmare, Ingle, S.V., Hajare, S. (2018). 'Effect of thyme essential oil on performance of broiler chicken', J. Entomol. Zool. Stud, 6, pp. 25-28.

Zhu, X., Liu, W., Yuan, S., Chen, H. (2014). 'The effect of different dietary levels of thyme essential oil on serum biochemical indices in Mahua broiler chickens', Italian Journal of Animal Science, 13, pp. 3238. 